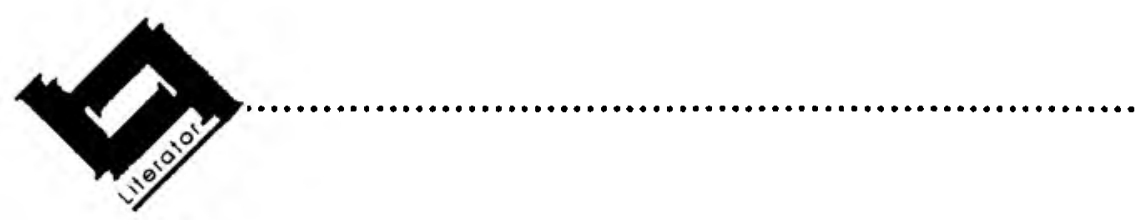

\title{
Speaking for the slave: Britain and the Cape, 1751-1838
}

\author{
Margaret Lenta \\ Department of English \\ University of Natal \\ DURBAN \\ E mall: lenta@mtb.und.ac.za
}

\begin{abstract}
Speaking for the slave: Britain and the Cape, 1751-1838

Postcolonial studies has asked the question "Can the subaltern speak?", but has focused less strongly on the strategies by which the subaltern is prevented from securing a hearing. The textual and social strategies used to prevent Cape sloves in the late eighteenth and early nineteenth centuries from voicing their plight have been neglected, though both pro- and anti-slavery lobbyists were eloquent. To present the slave as one whose inferiority rendered him incapable of pleading his cause was a device of the pro-slavery group; to pretend that consultation was impossible was another, though people who offered this defence were often surrounded by slaves. Others, accepting and profiting from the inequalities of a class-stratified society, were unable to perceive any but the extreme experiences of an unfree condition as constituting injustice. Anti-slavery campaigners were rarely in favour of the slave's being consulted: they preferred to condemn their political rivals, the slave-owners. Abolition found many of them searching for arguments to maintain the inequalities of society, and especially to prevent former serfs from securing a hearing.
\end{abstract}

\section{The silenced subaltern}

Since postcolonial theory became important to all critics of Third World literature, and to many critics of literature in general, subaltern studies, particularly identified with the name of Gayatri Spivak, but a preoccupation of many other critics, has become a concern of such critics. A gap in the textual production of a community, a failure of a particular group or category of persons within that community to produce text, has become significant; critics feel 
increasingly the obligation to study, not only text, but the absence of text. They are concerned not only with recorded discourse, but with the recovery of excluded discourse. As Spivak has claimed in her seminal essay, in order properly to understand a people, the question must be asked, "Can the subaltern speak?". She draws attention to the fact that "in the context of colonialist production, the subaltern has no history and cannot speak ..." (Spivak, 1995:28).

\section{The silenced slave}

Spivak's interest in her essay is finally in the period of postcolonialism, and in the obligation to grant speech to individuals and groups previously ignored. Within this essay, my own purposes are different but related: they are to extend backwards into the late eighteenth and early nineteenth century a specialised area of subaltern studies, that of the process of "silencing". Few words spoken by slaves, the group on which I shall focus, and those usually the heavily censored ones of court records, survive from this period. I shall therefore look at the attitudes and practices of power-holders which have led to the exclusion of these voices and interests from the political and historical processes. The voices of slaves, whose rights are legally as well as customarily fewer than those of even the lowest class of free people, are usually the least heeded in their day, and the least likely to be recorded for posterity. In the late eighteenth and early nineteeth centuries, though slaves were "silenced" in this sense, slavery was a matter of debate. Speech by slaves concerning their condition was replaced by speech by those who had an interest in interpreting that condition in terms of their own interests.

Elsewhere in her work Spivak remarks in a discussion of the rights of the oppressed to produce literary texts, "For me, the question 'Who should speak?" is less crucial than 'Who will listen?"' (Spivak, 1990:59). Her remark draws attention to the metaphoric quality of the term "silencing": of course the subalterns of whom she writes speak, as do the slaves of the period which I shall consider. But what remains for consideration in our own day is the discourse of those who refused to listen to them. In this discourse, the strategies of exclusion are revealed: some of the writers at whom I shall look lived amongst slaves, but nevertheless claimed that they were necessarily ignorant of the attitudes and desires of those slaves. Others (James Boswell is the example here), though they profited from the slave trade, not only avoided direct contact with slaves, but spoke with an assumed authority about their condition.

\section{Texts written in English in Britain and the Cape}

Partly because I wish to argue that the strategies of exclusion which I shall consider were part of a continuing British political practice, extended to the colonies, I shall confine myself in this article to texts written in English. Exception to this are a single quotation from the diaries of the German 
missionaries at Genadendal, whose words make it clear that they were aware of the ethos which I describe and Lichtenstein's Travels in Southern African in the Years 1803,1804, 1805 and 1806 (1828), which was first translated into English in 1812, close to its original publication in German, and which I include because its author is in conscious debate with John Barrow in his Travels into the Interior of Southem Africa (1802 \& 1806). The political practice of exclusion of voices, as feminist as well as postcolonial history and criticism have made us aware, has been not been purely British, but almost general. It has been related to the will of power-holders at once to serve their own interests and to maintain that they are not infringing the rights of other groups. Nevertheless the slavery debate in Britain and its colonies in the period 1770-1834 seems to me to deserve attention from critics interested in the "silencing" process. Where this debate is public, the slave is rigorously excluded from it, even by the writer/ speaker who strongly opposes slavery.

\section{Silencing as a practice in "unequal" societies}

This exclusion, even by a man like Barrow who is pleading for an alteration in the condition of the unfree, must lead us to question whether bondage and "silencing" can ever effectively be opposed in a society which denies political voice to the majority of its members: women and the unpropertied classes in general in the late eighteenth and early nineteenth century were censured for analysing or even describing their condition. Moreover, the period of which I have chosen to write, in the wake of the French revolution of 1789 , is one when British men of the ruling and professional classes are particularly defensive of class and gender privilege. Women of these classes, legally dependent on men and conditioned to see their interests as identical with theirs, tended to a similar conservatism. The single woman within the writers whom I shall cite, free to an extent that a man holding public office is not, but to an extent a prisoner within social and political structures, will allow me to question whether opposition to silencing can be mounted within such a group.

\section{David Hume writes of slavery, 1751}

The European roots of the racism which could provide an ideology tolerant of slavery were explored and theorised by the philosopher David Hume, in his Enquiry Concerning the Principles of Morals, first published in 1751. He claims that the motivation which underlies morality is "usefulness", that is to say, that men act "morally" in their dealings with one another because such behaviour serves their interests. In his section on justice he seems to consider appropriate behaviour in the free towards their slaves:

Were there a species of creature intermingled with men, which, though rational, were possessed of such inferior strength, both of body and mind, that they were incapable of all resistance, and could never, upon the highest 
provocation, make us feel the effects of their resentment; the necessary consequence, I think, is that we should be bound by the laws of humanity to give gentle usage to these creatures, but should not, rightly speaking, lie under any restraint of justice with regard to them, nor could they possess any right or property, exclusive of such arbitrary lords .... the restraints of justice and property, being totally useless, would never have place in so unequal a confederacy (Hume, 1951:190-191).

Hume goes on to state that "this is plainly the situation of men, with regard to animals", but his adjective "rational" makes it clear that he is not primarily concerned with pets or farm stock. Nevertheless, by remaining on the theoretical plane implied in the word "creatures" he has avoided the necessity of citing exact knowledge of enslaved peoples. His views, especially his belief that "usefulness" is the only shaping force in relations between people, are nonChristian, and Protestant Christianity was to remain the official religion of the British Isles for long after his death. Many members of the ruling class in the period, nevertheless, though they would have made no public renunciation of religion, were influenced in their conduct by such ideas. Utility, however, in Britain, was not a very strong motivation for slave-ownership: in the Cape Colony, as we shall see, where slavery was already established, it became strong enough to motivate British men and women to tolerate and even at times to defend slavery. "For most of the 1700s," writes Linda Colley (1996:371), "Britons had seen no inconsistency whatever between trumpeting their freedom at home and buying men, women and children from trading posts in Africa to sell abroad".

\section{Johnson and Boswell debate slavery, 1777}

James Boswell records in his Life of Johnson (1961:876-7) a discussion between himself and Johnson which took place in 1777 and which may represent both sides of the slavery debate, the humane and the commercially interested, as it was being carried on in Britain in the period. Johnson expresses his belief that slavery is evil and oppressive:

An individual may, indeed, forfeit his liberty by a crime; but he cannot by that crime forfeit the liberty of his children. What is true of a criminal seems true likewise of a captive .... He is certainly subject by no law, but that of violence to his present master; who pretends no claim to his obedience but that he bought him from a merchant of slaves, whose right to sell him never was examined (877).

This condemnation of slavery depends on reason and observation of mankind, a group of which, Johnson assumes, slaves are potentially equal members. Boswell then states his own position, the basis of which seems to be very different: 
To abolish a status, which in all ages GOD has sanctioned, and man has continued, would not only be robbery to an innumerable class of our fellow-subjects; but it would be extreme cruelty to the African Savages, a portion of which it saves from massacre, or intolerable bondage in their own country, and introduces into a much happier state of life; especiaily now when their passage to the West-Indies and their treatment there is humanely regulated. To abolish that trade would be to - shut the gates of mercy on mankind (878).

Boswell's argument is full of flaws: in what sense can God be considered to have "sanctioned" slavery? Where is his evidence that "African Savages" would be murdered were they not enslaved? How, since he has never visited Africa or Jamaica, does he know that the life of a plantation slave in the West Indies is happier that that of an African at home? And the claim that to abolish slavery would be to rob slave owners and traders depends on our accepting the premise on which the institution rests (and which Johnson has already refuted), that one man may justifiably own another. Behind Boswell's case is the doctrine of racial difference: "African savages" are lesser in their capacities and therefore in their rights, and may be brought to "a much happier state of life" when in bondage to whites. He is not disinterested: he writes of the folly and evil of abolishing "so very important and necessary a branch of commercial interest" (Boswell, 1961:878).

It is easy to understand why this discourse of assertion, of the repetition of generally-used defences, would be adopted by the British abroad, when they found themselves in territories where slavery (and later economic subjection of particular groups) was perceived as necessary to the economy. But Johnson's belief in shared humanity, and in the right to freedom of all but those who are found guilty of serious crime (and although he had personal knowledge of enslaved people, he does not cite it), also continues as an influence.

\section{The slavery debate at the Cape: the governor's view}

The terms on which the Cape was ceded to the British in 1795 established only an interim government, since their right to rule there was officially based on the temporary presence of the Prince of Orange in Britain as a refugee. Any change in the laws relating to slavery, or to the near-serfdom of the Khoikhoi on Dutch farms, was forbidden by the articles of cession. The British, coming from a country where the condition of slavery had been outlawed for more than twenty years, found themselves surrounded by slaves, and more or less obliged, if they wanted servants, to become slave owners.

In 1797 a civil governor, Lord Macartney, and his staff arrived in Cape Town to take over the administration. Macartney was an experienced and enlightened man, a member in his youth of Dr. Johnson's Literary Club and a friend of 
David Hume. In a colony where the supply of free artisans and labourers was small, and where the population had recently been increased by "between four and five thousand Men, a navy of eighteen or twenty ships of war, an increasing number of trading vessels and merchants" (Macartney: Private Letter, July 24 1797), he felt himself forced to sanction the import of slaves. In defence of his act, he wrote to Henry Dundas, the British Minister for War, offering a view of slavery which resembles Boswell's:

The question was, whether in a state of actual necessity, we were to listen most to the dictates of good sense, and public duty, or to the whims and ravings of ignorance and fanaticism. - It appeared to me an indispensable obligation, rather to provide for the subsistence of the People committed to my care, and of His Majesty's fleet and army in esse, than to argue with myself what might be the possible felicity of freedom to the unknown Blackamoors. I paid, however, such respect to the prejudices of the day, as to confine my licence to a single Ship, and shall be cautious in extending it, till the proper authority shall have decided this point, which seems to have been at issue for some years past between rashness and experience, thoughtfulness and reflection, ancient wisdom and modern philosophy. In the mean time, as the slaves for this colony are brought from the short distance of Mozambique and Madagascar, they have to encounter neither the hobgoblins of the middle passage, nor the scramble of a west India market. The negros in general whom I have seen here, appear to me to be remarkably well treated. Their food is little inferior to that of their masters, and their labor much less than an English peasant's. As to sentiment, I imagine them to have sufficient to teach them their condition, and to convince them, that if it was made better, that of others must be made worse; for as long as Providence shall think fit that some men should be wiser and stronger than others, so long must the duller and the weaker submit to its decrees, and be content with inferiority and dependence (Macartney: Private Letter, July 24 1797).

I have presented Macartney's case at length because it is an excellent example of an official British colonial pro-slavery discourse, strongly motivated by the Humean concept of "usefulness", and by a token sense of the humane. The fact that it is in a private letter, as opposed to an official dispatch, shows Macartney's awareness that slavery in British colonies is a matter of debate in Britain itself. He labels the anti-slavery lobby "ignorance and fanaticism", as opposed to the "good sense and public duty" which characterise his own position. A further antithesis, between "the People committed to my care" and "His Majesty's fleet and army" as opposed to "unknown Blackamoors" marks the beginning of an "othering" process similar to that implied by Boswell's phrase "African Savages". And my earlier contention that a society which customarily denies rights to large groups within it will be particularly ready to silence slaves is upheld here: the comparison with the "English peasant" is a reminder that in England similar or worse conditions are tolerated. 
Macartney's physical position vis á vis African slaves is, however, different from Boswell's when he generalises about savages. At the Cape Macartney is in daily contact with such people: why does he not ask them how they feel about their lives of servitude? And if he cannot know them, how can he assert that they belong to "the duller and the weaker" of mankind? The answer must be that he is motivated to preserve intact assumptions about Cape slaves which resemble those of Hume about the "species of creature" which need not be treated "justly".

\section{What Lady Anne Barnard saw - and did not see}

Macartney claims that slaves brought to the Cape are fortunate in that they avoid the Middle Passage. This in a literal sense must be true, but Lady Anne Barnard, living at the Cape at the same time, records that she has witnessed a landing of slaves, and spoken to the white clerk who was supervising it about the slaves' conditions on the voyage from Mozambique: "How comes that that six hundred and odd slaves coud ${ }^{1}$ come in one ship? - another shrug, they must have been certainly much crowded, but no great number died on the voyage - how many? - only 50" (Barnard: March 10 1800). What seems to be vital here is that the writer is willing to record an actual experience; witness to a slave landing, she writes as she sees. She cannot, of course, understand the speech of these Mozambiquans, but it is remarkable that she never, despite the generous compassion which is one of her leading qualities, asks one of the slaves who works in her own house what he thinks of his condition. When she records the words of slaves, they are speaking in Dutch to her about her domestic concerns.

Though Lady Anne was a friend of Macartney, and would never have conceived of herself as in opposition to him, she is the author of a text which, however unintentionally, by offering a factual record of observations of slaves, opposes and discredits the Macartney/Boswell kind of pro-slavery rhetoric. 1 have shown elsewhere that she offers in her diaries a detailed account of individual slaves, and is willing to discuss the areas of their lives which most writers, for their own political purposes, ignore (Lenta, 1992:55-68). Slave sexuality is a major one: she explicitly opposes the general belief that slaves are promiscuous and undiscriminating in their sexuality, explaining that "[amongst the Slaves] there is no marrying or giving in marriage, tho' there is often constancy from choice" (Barnard, 1995:189). Equally she discredits the idea that slaves are more licentious than whites by recording that they are often the subjected partners of British men, the head of the garrison and later governor, Francis Dundas, her own brother John and her husband's secretary, Hercules Ross, amongst them. But since she is loyal to a society which tolerates men of the upper class who

1 Original spelling used by Lady Anne Bamard retained in quotations 
take concubines from lower classes, she does not censure the white men, nor particularly pity the slave women.

She does, however, observe that the slaves possess a strict moral code, which is different from and indeed oppositional to that of their masters:

... a slave will much rather suffer death than give up his accomplice .... every thing depends on the first principles of right $\&$ wrong that is instilld in the mind, the principle of good faith \& secrecy in thieving is inculcated in the black infant with its mothers milk for it hears how much its Faeder has born to screen Scipio or Brutus - it cannot hear thieving condemned because it is not esteemd a sin amongst the slaves, they love the pleasures the pilferd goods purchases $\&$ woud gladly take the pleasure at the expence of the flogging, they know they will not be Hanged, or floggd more than they bear as they are the property of the master $\&$ he will not hang them for his own sake - (Barnard June 22 1799).

Puzzled by the fact that her slaves, who could confidently ask her for tobacco, wine or small sums of money, prefer to steal them, she nevertheless refuses to interpret their actions beyond condemning them as sinful. The idea that subjected people may desire, not favours from their masters, but a degree of autonomy, and that their thieving represents rebellion against their condition is one which her class position prevents her from entertaining. As a lifelong employer of servants whose class position prevents them from aspiring to change their rank she can only pity what is particular to slavery, that is to say, the kidnapping from their families and country, exposure at the slave auction, or brutal punishment.

She is aware that the prohibition of knowledge for those who might bear witness is one of the ways in which slavery is rendered defensible, and outlines her own contrary ethos when she is told that slaves have no feelings and enjoy being probed before being auctioned:

... as one is told many things which on closer inspection, and judging with an impartial \& investigating eye into countinances one does not find to be true, I wishd to consider the countinances of each poor slave, look at his eyes, \& try to discover if there were any minds amongst them (Mar 14 1799).

The auction is peculiar to slaves, and she wishes to investigate it; she does not avail herself of the many opportunities for probing the attitudes of those who work in her house.

\section{Robert Semple's ethno-tourism}

There can, of course, be no truly impartial account of slavery; everyone who writes of it has his or her reasons for doing so. Robert Semple, who lived at the 
Cape as a merchant and shopkeeper from 1798 until about the end of 1803 (Semple, 1968:6-7) and published a book entitled Walks and Sketches at the Cape of Good Hope in 1803, shows the ambivalence which belongs to the British in Cape at this period, when society was still bound by the laws established by the previous, Dutch, regime. Obliged by his sense of his British readership, he at once deplores slavery, and explains that at the Cape "in the very bosom of slavery" (Semple, 1968:37) it is almost natural. He writes of his observations in Cape Town:

Domestic slavery has at all times and in all nations been productive of much evil. A pampered slave is insufferably insolent; an oppressed one is constantly trembling and cringing, and by the daily sight of either, the heart of youth is necessarily hardened and depraved (Semple, 1968:36).

It is notable that it is only domestic (not plantation) slavery that he condemns, and that it is the corruption of the master's children which preoccupies him. And in his "walk" through the city, when he comes across a slave auction, his preoccupation is the depiction of a pathetic scene when mother and infant are separated, rather than any indignation at the general condition of slavery. He has an evident commercial purpose in his accounts of the different enslaved peoples of the Cape. He divides them into groups - Mozambiquers, Malays, Malabars and Hottentots - and generalises, in a manner which one can only call ethnotouristic, about the appearance and behaviour of each group.

Observe the one who comes next. Even at a distance his upright form, his nervous make, his free step announces the Malay, or native of the Island of Java, the king of slaves. As he approaches, mark his long, coal black hair which hangs half down his back, his yellow complexion, his glancing and jealous eye, which looks askance upon slavery. He knows well that from his class are formed the house-painters, the musicians, the ingenious workmen of the Cape. He is proud of this distinction, and glories in the name of Malay (Semple, 1968:47-48)

Cape Malay slaves, already distinguished for their skills, made arguments like those of Hume, Boswell and Macartney concerning "savages" or "the duller and weaker" of mankind impossible. Semple (1968:48) writes that the Malay, beaten or insulted, may finally "rush upon his unguarded master with his kris or crooked dagger and stab him ..." It must have been hard not to see this as a spirit reacting to intolerable and undeserved oppression, but Semple's little book "sells" Cape slavery as a piece of armchair tourism: this is one of the horrifying but exciting phenomena of a far-off land. He is willing in this sense to "market" the slaves, picturesque in their dress and exotic in their behaviour. 


\section{Barrow and Lichtenstein debate for and against serfdom}

Two extensive accounts of Cape slaves and serfs, which are in conscious opposition to each other, exist, by John Barrow and Heinrich Lichtenstein respectively. Barrow travelled in the Cape hinterland in 1799 and Lichtenstein in 1803-1806. Barrow published the first volume of his Travels into the Interior of Southern Africa in 1802, shortly after the Peace of Amiens, which accepted that the Cape must be returned to the Dutch, and before this return was effected. Lichtenstein, who wrote in German a work translated as Travels in Southerm Africa in the Years 1803,1804,1805 and 1806 (Lichtenstein, 1812), was one of the party sent to re-establish Dutch rule at the Cape in 1803. These two writers belong to a debate ostensibly about slavery but really about rival colonial regimes. Both are concerned with slaves and bound Khoikhoi workers, whose position relative to their employers is such that they can be included in the same discussion as slaves.

Barrow, a member of Macartney's staff, undertook and reported on the travels on which he later based his books on the orders of Macartney, who was already contemplating the large scale account of the Cape entitled "Sketches of the Political and Commercial History of the Cape", in which the potential of the colony for British settlement is assessed. Mary Louise Pratt, in her discussion of Barrow's Travels, though she is not unaware that they share a common origin with the Macartney Sketches, does not understand that this is the reason why the indigenous peoples are "traces on the landscape" (Pratt, 1992:59). Nor does she seem to realise that the Cape Dutch are reviled as competitor-colonists. Barrow, partly at least because on this occasion his mission is to discredit the Dutch, has a different set of assumptions about slavery from those revealed in the governor's private letter quoted above. In his preface, preparing his readers for his account of the Khoikhoi, he writes that "there are still to be met with hordes of natives, who, though suffering unmerited ill usage, have yet escaped the horrors of slavery" (Barrow, 1806:v). The implication seems to be that slavery and the condition of indigenes in the Cape Colony in the period are different, and the sufferings of the Khoikhoi less than those of the slaves, but his text in fact advances the opposite argument. The strongest possibility seems to be that he regarded the position of Cape slaves, whose ancestors, or who themselves had been brought by sea into the colony, as worse because more difficult to alter, since it could only be changed by a shift in government policies. The Khoikhoi's bondage to their employers was in his view an abuse. Government might more easily intervene to regulate contracts and to make them aware that they were being duped.

Part of the value of Barrow's book is that it distinguishes between the types of slavery and serfdom present in the Colony, and at times obscured by differences of discourse which were not fortuitous. He describes the peoples imported from Mozambique and sold on arrival, the San prisoners of war who have been 
rendered slaves by government decree, and the "Hottentots" (Khoikhoi) who serve the Dutch on contracts which deprive them and their children of freedom of movement, and oblige them to accept small reward for their services and brutal punishment for transgression. He contradicts the suggestion of his preface that the Khoikhoi are fortunate in avoiding slavery; they are, he says, of less value to the farmers than slaves, and therefore worse treated. A farmer may beat them, cut them, fire small shot into their legs, and care little for their deaths, "for though they are to all extents and purposes his slaves, yet they are not transferable property" (Barrow, 1806:94). He explains the condition of the San within the Colony:

[the Dutch government of the Cape] decreed that such of the Bosjemans as should be taken alive in the expeditions made against them, were to be distributed by lot among the commandant and his party, with whom they were to remain in a state of servitude during their lives (Barrow, 1806:189$190)$.

The main means of Khoikhoi subjection is the establishment of settler farms which make nomadic pastoralism impossible, but the consensus amongst their Dutch employers that they be employed only on contracts which grant them small wages is also crucial, as is the law which stipulates that any child born to them whilst in employment shall be the property of the farmer for twenty-five years. Barrow (1806:93) writes with compassion:

These weak people, the most helpless, and in their present condition the most wretched, of the human race, duped out of their possessions, their country, and their liberty, have entailed upon their miserable offspring a state of existence to which that of slavery might bear the comparison of happiness.

Even Khoikhoi who work by the year on Dutch farms, rather than on a longer contracts, may find their children claimed by the Dutch farmer, who will simply prevent their parents from taking them when they leave his farm (1806:96). "Othering", in the sense of viewing a whole people as undifferentiated, innately inferior and properly subjected, is an essential part of the Dutch attitude to the Khoikhoi: Barrow (1806:395-6) writes of a Khoikhoi woman and her baby who were beaten almost to death by a farmer as a revenge on her people for the rebellion of 1799 .

Because to be a Christian is to be a member of a group whose members, at least ideally, are united by mutual love and duty, Christianity has become in the relations between master and bondsman the marker between Dutch self and Khoikhoi other: a farmer who had kept a Khoikhoi child in fetters was punished by the British by being himself fettered, and spent the night screaming, "My God! Is this a way to treat Christians?" (Barrows, 1806:396-398). In the period, a slave or indigene had to receive official permission to receive baptism, which 
seems to have conferred something like assimilado status. Lady Anne Barnard, for example, records in June 1800 the gratitude of a black woman to whom her husband had given permission to be baptised, and who now trades in Cape Town. At least, the status of Christian was an obstacle to the "othering" process, and therefore the conversion of slaves and Hottentots to Christianity was often opposed by the Cape Dutch. The Herrnhut missionaries at Genadendal, in their report on the reception of Hottentots into the church in August 1793, summarise the belief in the equal brotherhood of Christians, and inadvertently explain the antagonism between missionaries and farmers which was already developing: "On the 31 st we told the baptized that they should no longer call us masters, but brothers" (Bredekamp et al., 1992:130).

Lichtenstein's Travels in Southern Africa in the Years 1803, 1804, 1805 and 1806 explicitly opposes Barrow, who, the author claims, "dips his pen in the bitterest gall" when describing the Dutch (Lichtenstein, 1812:50-51). He describes a slave a hundred and twenty years old, full of gratitude to his master who maintains him though he can no longer work, and is insistent that that Barrow's "odious representations ... of the behaviour of masters ... have rather been taken from particular cases which ought to have been cited as exceptions" (Lichtenstein, 1812:61). We meet a distinguished colonist, Jacob van Reenen, who maintains an orchestra of slaves, as do many other Cape families. Lichtenstein comments that "there are many freed-men at the Cape who gain their living by instructing the slaves in music: but neither master nor scholars knows a single note: they all play entirely by ear" (Lichtenstein, 1812:34). Lichtenstein believes himself to be revealing the limits of slave ingenuity, but the prohibition on slaves' learning to read is almost universal.

\section{The Cape Dutch as gentry or peasantry}

Lichtenstein (1812:74) travels through the colony, describing the Dutch in terms appropriate to a benevolent rural gentry. "A strict regard to the bodily health of his slaves we observed indeed to be conspicuous throughout every part of the worthy farmer's establishment". When it comes to the Khoikhoi, Lichtenstein (1812:84-85) quotes the account of a farmer named Rossouw, who complains of them in language which J.M. Coetzee in his "Idleness in South Africa" (1988: 12-35) has made familiar to us, "When they are reduced to great want, they come to him and other inhabitants of the neighbourhood to offer their services. ... They cannot at the same time be accused of any actual wickedness - their characteristic vice is extreme indolence". The implication is not that, as Barrow has claimed (and Macartney in his account of the Cape strongly supports this view), the terms on which they are obliged to work are unattractive, but that they fail in their obligation to take permanent service under the Dutch.

We must take seriously Lichtenstein's point that it is on the selection of evidence that Barrow's conclusions about the Dutch as employers of bound 
labour depends - but this is equally true about his own conclusions. In both men's texts there are clues to the reasons behind the differences between them. Barrow believes that the model which should form the behaviour of the rural Dutch is that of a diligent, labouring peasantry; his unvoiced implication is that authority over others is appropriate only to the British. And like Semple, though much more cogently, he bases his objections to serfdom on the fact that it degrades the master:

The boor notwithstanding has his enjoyments: he is absolute master of a domain of several miles in extent, and he lords it over a few miserable slaves or Hottentots without control ... Unwilling to work, and unable to think, with a mind disengaged from every sort of care and reflexion, indulging to excess in the gratification of every sensual appetite, the African peasant grows to an unweildy size, and is carried off the stage by the first inflammatory disease that attacks him (Lichtenstein, 1806:28-29).

Lichtenstein, as I have pointed out, sees the Dutch as rural gentry, and the proper masters of Khoikhoi and other subject peoples. Present day historians have agreed that this was the sense which the Cape Dutch had of themselves: Dooling (1994:32) comments that [t] he eighteenth century saw the emergence of a "Cape gentry", and Morton has shown that the trekboers felt entitled to supply themselves with slaves from the indigenous peoples whom they encountered (Eldredge \& Morton, 1994:1-5).

\section{The abolition of slavery and its aftermath: Pringle and Baines}

Slavery was to be abolished legally in 1834 , and to disappear more gradually as a reality from South Africa. The debate concerning the rights of the racial Other continued into the nineteenth century in a manner closely related to the slavery/serfdom debate: Thomas Pringle, an 1820 settler, in his Narrative of a Residence in South Africa (1834), records an occasion on which he met a Xhosa woman condemned to servitude "for crossing the line of prescribed demarcation [on the frontier between the colony and Xhosaland] without permission". He describes the woman, hearing her sentence, as begging for mercy:

The language, to which she appeared to give full and forcible intonation, was highly musical and sonorous; her gestures were natural, graceful and impressive, and her large dark eyes, and handsome bronze countenance, were full of eloquent expression. Sometimes she pointed back towards her own country, and then to her children. Sometimes she raised her tones aloud, and shook her clenched hand, as if she denounced our injustice and threatened us with the vengeance of her tribe. Then again she would melt into tears, as if imploring clemency, and mourning for her helpless little ones. Some of the villagers who had gathered round, being half or whole Caffers, understood her speech, and interpreted its substance in Dutch to the 
missionary, but he could do nothing to alter her destination, and could only return kind words to console her (Pringle, 1986 (1834): 13).

What is most interesting in this passage is Pringle's attempt to give speech to the Xhosa woman; unable to translate, he interprets - we might say fictionalises her utterances. The assertion of government which informs her sentence is that, not withstanding the small class of free blacks (manumitted slaves and their descendants), indigenes within the colony ought to be in servitude. Pringle, who left the colony in 1826, well before slavery was abolished, is attempting in terms of his own anti-slavery principles to give the woman the means to counter-assert her equal humanity. Few settlers would have agreed with him: Andrew Geddes Baines's poem "Kaatje Kekkelbek or Life among the Hottentots", which was performed in Grahamstown in 1838 (Chapman, 1981:51), is very different in tone. Though the poem puts words into the mouth of a black woman, there is not even an attempt to claim that Baines's purpose is mimetic. Kaatje is required for purposes of political and comic effect to convict herself of drunkness, promiscuity and theft. The poem, which remained popular long after Baines's death, makes the opposite claim from Pringle's book, that the missionaries indulge savages and allow them to be idle. The discipline of servitude, it is implied, is necessary to these people.

\section{Conclusion}

Since slavery was eventually abolished in South Africa, does it matter that the slavery debate was carried on over the heads of "silent" slaves? Baines's "Kaatje Kekkelbek", significantly written in 1838, when the four-year apprenticeship of ex-slaves came to an end, seems to me to demonstrate that it does. Baines's interest is in the transformation of slavery into some other kind of servitude, in arguing that the Khoikhoi are incapable of any kind of equality with the settlers. He has chosen the most effective means of silencing them in speaking for them. It is a means derived from the slavery debate at the Cape and is to be used, though often much contested, for the next hundred and fifty years. Significantly, Kaatje is made shameless, dehumanised, in order that she may say what Baines and his fellow-settlers wish to believe.

Pringle's account of the Xhosa woman captive equally puts words into her mouth, as it must, since he and his audience do not understand Xhosa. He attributes to her, however, the love of family and home normal in his own group, and goes as far as he can to help her to speak her humanity. By giving her, and by implication her group, equal humanity with his own, he is accepting that she must speak for herself. In his narrative, the subaltern speaks; the failure is that of the reader who cannot hear without an interpreter. 


\section{References}

Barnard, Lady Anne. (Unpublished) Diaries for 1799 and 1800. In the possession of the Earl of Crawford

Barnard, Lady Anne. 1995. The Cape Journals of Lady Anne Barnard, 1797-1798. Ed. Lewin Robinson, Anthony. Cape Town : Van Riebeeck Society.

Barrow, John. 1802 \& 1806 Travels into the Interior of Southern Africa. 2 vols. London : Cadell \& Davies.

Boswell, James. 1961. Boswell's Life of Johnson. Preface by R W. Chapman London Oxford University Press

Bredekamp, H C., Flegg, A.B.L \& Pluddemann, HF. 1992. The Genadendal Diaries Vol. I (1792-4). Bellville : University of the Western Cape Institute for Historical Research

Chapman, Michael 1981. (ed) A Century of South African Poetry. Johannesburg : Donker.

Coetzee, J.M 1988. White Writing: On the Culture of Letters in South Africa. Sandton Radix.

Colley, Linda 1996. Britons: Forging the Nation 1707-1837. London : Vintage.

Dooling, Wayne. 1994. The Good Opinion of Others: Law, Slavery and the Community in the Cape Colony, c1760-1830. In: Worden, N. \& Crais, C. Breaking the Chains: Slavery and Its Legacy in the Nineteenth Century Cape Colony. Johannesburg : Witwatersrand University Press p. 25-43.

Eldredge, Elizabeth A. \& Morton, Fred 1994 Slavery in South Africa: Captive Labour on the Dutch Frontier. San Francisco \& Pietermaritzburg : Westview Press and University of Natal Press.

Hume, David. 1951. Enquiries Concerning the Human Understanding and Concerning the Principals of Morals by David Hume. Ed Selby-Bigge, L A London : Oxford University Press.

Lenta, Margaret 1992. Degrees of Freedom: Lady Anne Barnard's Cape Diaries. English in Africa, 19(2):55-68

Lichtenstein, Henry. 1928 (1812). Travels in Southern Africa in the Years 1803, 1804, 1805 and 1806. Trans. Plumptre, Anne. Cape Town : Van Riebeeck Society.

Macarney, George. Private Letter to Henry Dundas. MS 63/8, May 71798 Johannesburg, Brenthurst Library.

Macartney, George. (Compiled 1798-9.) Sketches of the Political and Commercial History of the Cape of Good Hope. Unpublished. Two MS copies, (MSS 60, 61) Johannesburg, Brenthurst Library.

Pratt, Mary Louise 1992 Imperial Eyes. Travel Writing and Transculturation London \& New York : Routledge.

Pringle, Thomas 1986 (1834) Narrative of a Residence in South Africa. Vol 1. Brentwood The Empire Book Association

Semple, Robert 1968 (1803) Walks and Sketches at the Cape of Good Hope. (ed.) Bradlow F R Cape Town \& Amsterdam : Balkema.

Spivak, Gayatri Chakravorty. 1990. The Post-Colonial Critic. Interviews, Strategies, Dialogues (ed Harasym, Sarah) London : Routledge.

Spivak, Gayatri Chakravorty. 1995. Can the Subaltern Speak? In: The Post-Colonial Studies Reader Ed. Ashcroft, B., Griffiths, G \& Tiffin, H. London and New York : Routledge p. 24-28. 
